\title{
Anna Lipka
}

Uniwersytet Ekonomiczny w Katowicach

e-mail: anna.lipka@ue.katowice.pl

\section{MOŻLIWOŚCI WYKORZYSTANIA NARZĘDZI CONTROLLINGU PERSONALNEGO W ZARZĄDZANIU ZORIENTOWANYM NA ZDARZENIA KRYTYCZNE W ŻYCIU PRACOWNIKÓW}

\section{POSSIBILITIES OF USING PERSONAL CONTROLLING TOOLS IN MANAGEMENT FOCUSED ON CRITICAL EVENTS IN EMPLOYEES LIVES}

DOI: $10.15611 / \mathrm{pn} .2018 .511 .13$

JEL Classification: M54

Streszczenie: Celem opracowania jest krótka charakterystyka - nieudokumentowanej w literaturze krajowej (ani w formie opisu, ani badań empirycznych) - koncepcji zarządzania zorientowanego na zdarzenia krytyczne w życiu pracowników. Przedstawiono ją na tle innych znanych koncepcji oraz w kontekście aktualnej sytuacji na rynku pracy. Dokonano specyfikacji kategorii zdarzeń krytycznych stanowiących przedmiot tej koncepcji. Instrumenty zarządzania zorientowanego na zdarzenia krytyczne w życiu pracowników podzielono ze względu na ich kosztochłonność. Następnie zaproponowano instrumentarium controllingu personalnego, które może być przydatne w jej implementacji. Ma ono postać mierników, wskaźników, a także list kontrolnych (pytań do zjawisk o charakterze jakościowym). Rozwinięto dzięki temu tezę, iż możliwy jest controlling wdrożenia koncepcji obejmujący trzy szczeble, tj. koszty, jakość i efektywność.

Słowa kluczowe: zdarzenia krytyczne w życiu pracowników, controlling personalny, controlling efektywności.

Summary: The aim of the study is a brief characteristic - not yet presented in Polish literature (neither in a form of a description nor empirical research) - of the concept of management focused on critical events in the life of employees. It was presented against other well-known concepts and also in connection to the current situation on the labor market. Different categories of critical events related to this concept have been specified. All management tools concerning critical events in the life of employees were divided due to their cost-intensive nature. Next, a personnel controlling tool, which can be useful in the concept implementation process, has been proposed. It has the form of measures, indicators and checklists (questions about phenomena possessing qualitative nature). The above, proved the hypothesis that it is possible to control the implementation of the concept referring to three factors: cost, quality and efficiency.

Keywords: critical events in employees live, personnel controlling, effectiveness controlling. 


\section{Wstęp}

Koncepcji zarządzania zorientowanego na zdarzenia krytyczne w życiu pracowników warto przyjrzeć się w warunkach nadwyżek popytu na pracę nad podażą pracy w wielu segmentach rynku pracy z uwagi na jej kompatybilność z tymi warunkami. Wchodzi ona w zakres tzw. empatycznego zarządzania (szerzej na ten temat w [Lipka $\mathrm{i}$ in. 2018]), manifestującego się m.in. w tzw. przywództwie służebnym (servant-leadership) [Greenleaf 1977, s. 336]. Ma punkty styczne z innymi koncepcjami zarządzania, takimi jak: Employee Relationship Management (zarządzanie relacjami z pracownikami), pozytywna teoria organizacji (Positive Organizational Scholarship), zarządzanie różnorodnością, zarządzanie przez zaufanie czy koncepcja zrównoważonego zarząazania zasobami ludzkimi.

Celem niniejszych rozważań jest wykazanie, iż w odniesieniu do zarządzania zorientowanego na zdarzenia krytyczne w życiu pracowników mogą być stosowane wszystkie trzy szczeble implementacji controllingu personalnego w rozumieniu R. Wunderera [2000, s. 303]. Rozwinięto zatem następującą tezę: controlling implementacji zarządzania zorientowanego na zdarzenia krytyczne w życiu pracowników obejmować może: controlling kosztów, controlling jakości oraz controlling efektywności. Rozwinięcie to oparto na skonstruowaniu - na podstawie opisów koncepcji zawartych w literaturze przedmiotu - mierników/wskaźników oraz list kontrolnych, czyli „aparatu metodycznego” controllingu dotyczącego analizowanej koncepcji. Główne treści poniższych rozważań podzielono zatem na trzy wymienione obszary controllingu. Poprzedzono je opisem koncepcji zarządzania zorientowanego na zdarzenia krytyczne w życiu pracowników, gdyż - jak wynika z przeprowadzonego studium literatury przedmiotu - nie dokonywano dotychczas rozwinięcia określonego w tezie, a sama koncepcja jest rzadko szczegółowiej prezentowana (jednym z nielicznych źródeł bibliograficznych na ten temat jest książka pod red. S. Armutata [2009]).

\section{Idea zarządzania zorientowanego na zdarzenia krytyczne w życiu pracowników}

Zarządzanie zorientowane na zdarzenia krytyczne w życiu pracowników oznacza indywidualne (niezależne od fazy cyklu życia w organizacji) podejście do osoby doświadczającej silnych (rzutujących na sferę poznawczą i przebieg procesów poznawczych, a także sferę emocjonalną i behawioralną) zmian w związku z [Böhne 2009, s. 40-49]:

- podjęciem pracy w firmie,

- uzyskiwaniem kwalifikacji,

- „przekraczaniem” stopni na ścieżce kariery,

- byciem uczestnikiem zmian organizacyjnych,

- włączeniem się w aktywność społeczną poza firmą, 
- „wyjściem” z organizacji (spowodowanym odejściem bądź zwolnieniem),

- zaistnieniem znaczących zmian sytuacji w życiu prywatnym.

Szczególną rolę wśród tych zdarzeń zajmują (stanowiące przedmiot szczególnego zainteresowania w niniejszym opracowaniu) zdarzenia krytyczne, nieobejmowane zazwyczaj „rutynowymi” działaniami z zakresu HR (Human Resource), czyli zdarzenia dotyczące sfery prywatnej pracownika. Stanowią one nierzadko temat tabu, niekiedy związany z „danymi wrażliwymi”. Rzutują jednak na możliwości, przebieg oraz efekty pracy, a zatem - o ile pracownik czyni na to przyzwolenie - nie powinny być obojętne pracodawcy dbającemu także o społeczne środowisko pracy (i to nie tylko w kontekście dbałości o atrakcyjność/wizerunek na rynku pracy). Zresztą zachowanie zdolności do pracy osoby dotkniętej zdarzeniem krytycznym stanowi ważny cel zarządzania zorientowanego na zdarzenia krytyczne w życiu pracowników. Koncepcja ta łączy zatem stosowanie indywidualnych strategii radzenia sobie z trudną sytuacją [Heszen, Sęk 2007, s. 144-154] ze wsparciem ze strony organizacji, które wpływa zarówno na sytuację jednostki, jak i zespołu, w którym ona funkcjonuje (stanowiąc szansę bądź zagrożenie dla funkcjonowania zespołu). Bazuje na nadaniu wysokiej rangi empatii, inteligencji emocjonalnej i zaufaniu w organizacji. Wymaga więc pracy emocjonalnej [Hochschild 2009, s. 6-7 i 12], z czym wiąże się taka jej wada, jak podwyższone ryzyko wypalenia zawodowego u osób ją wykonujących. Wdrażaniu koncepcji sprzyjają określone typy kultury organizacyjnej (np. kultura ekspresyjna) oraz rodzaje strategii personalnych (np. strategia transformacji).

\section{Controlling kosztów}

Controlling kosztów, w ramach którego mieści się controlling kosztów pracy, zorientowany jest na dotrzymywanie ustaleń budżetowych. W jego ramach może być określana przewidywana i rzeczywista struktura zdarzeń krytycznych, w przypadku których zastosowana będzie koncepcja zarządzania zorientowanego na zdarzenia krytyczne w życiu pracowników. Przewidywana struktura, w odniesieniu do znaczących zmian w życiu prywatnym, może kształtować się następująco (procentowy udział zdarzeń tej kategorii w ich ogólnej liczbie):

- wypadek/choroba własna, osoby bliskiej - a\%,

- urodziny dziecka, wnuka - b\%,

- śmierć w bliskiej rodzinie - c\%,

- ślub - d\%,

- rozwód, separacja - e\%,

- opuszczenie domu przez dorosłe dzieci - $\mathrm{f} \%$,

- oczekiwanie na diagnozę dotyczącą ważnych aspektów zdrowia - g\%,

- dłuższa rozłąka z małżonkiem, z bliskimi - h\%,

- zmiana pracy, jej warunków lub przejście na emeryturę małżonka/partnera - i\%,

- konflikt w rodzinie, sąsiedztwie - j\%, 
- $\quad$ przeprowadzka - k\%,

- utrata domu, mieszkania - 1\%,

- ciąły stres spowodowany koniecznością spłacania kredytów - ^\%,

- podleganie karom w wyniku naruszenia prawa - m\%.

Przedmiotem controllingu mogą być odchylenia przewidywanej i rzeczywistej struktury tego rodzaju zdarzeń krytycznych, gdyż pociągają one za sobą zmiany dotyczące kosztów. W ramach stosowanej koncepcji, pracownikom udzielane może być wsparcie w postaci następujących kategorii instrumentów:

- zarządzania czasem,

- $\quad$ projektowania pracy (job design),

- $\quad$ organizacyjno-psychologicznych, a także dotyczących rozwoju i wynagradzania pracowników.

Jako mierniki/wskaźniki controllingowe można wyznaczać:

- $\quad$ pożądany (z perspektywy zarządu organizacji) i faktycznie najczęściej wybierany instrument wsparcia,

- $\quad$ wskaźnik dynamiki pracowników korzystających ze wszystkich/z poszczególnych instrumentów bądź ich kategorii,

Tabela 1. Instrumenty zarządzania zorientowanego na zdarzenia krytyczne w życiu pracowników ze względu na ich kosztochłonność - przykład

\begin{tabular}{|l|l|}
\hline \multicolumn{1}{|c|}{$\begin{array}{l}\text { Instrumenty o raczej wysokiej } \\
\text { kosztochłonności }\end{array}$} & \multicolumn{1}{c|}{ Instrumenty o raczej niskiej kosztochłonności } \\
\hline - Urlop bezpłatny & - Urlop wypoczynkowy w „nietypowym terminie” \\
- Przejście na etat w niepełnym & - Elastyczny czas pracy, zmiana godzin pracy: „na sztywne”, \\
wymiarze & na elastyczne \\
- Zmiana wymiaru godzin & - Akceptacja nieprzewidzianych przerw w pracy \\
nadliczbowych & - Zmiana treści pracy \\
- Wyłączenie z pracy zmianowej & - Zmiana formy organizacji pracy \\
- Przedłużenie terminu wykonania & - Realokacja na inne stanowisko/redefinicja roli w zespole \\
pracy & - Zmiana miejsca wykonywania pracy: w domu, mobilne/ \\
Zmiana wolumenu & zdalne, w siedzibie firmy \\
dotychczasowego zadania & - Zmiana zakresu autonomii pracy \\
- Zorganizowanie zastępstwa & - Adaptacja po przerwie w pracy \\
& - Możliwość zabrania do pracy osoby, nad którą musi być \\
& sprawowana opieka \\
& - Wsparcie psychologiczne \\
- Ograniczenie/dostosowanie do pracowników terminów \\
delegacji służbowych i szkoleń
\end{tabular}

Źródło: opracowanie własne. 
- stopień różnorodności wykorzystania (kategorii) instrumentów (liczba wykorzystywanych w określonym czasie pomnożona przez $100 \mathrm{w}$ stosunku do ogólnej liczby (kategorii) instrumentów wsparcia oferowanych w tym czasie),

- wskaźnik odchylenia od równego podziału (dodatnie/ujemne wskazuje, ile procent więcej/mniej (kategorii) instrumentów wsparcia jest faktycznie wykorzystywanych w porównaniu z równym korzystaniem z nich).

Kształtowanie się wartości tych wskaźników w połączeniu z analizą odpowiedzi na „pytania kontrolne” typu: „Dlaczego nie skorzystał(a) Pan(i) z instrumentu wsparcia „x” w przypadku zdarzenia krytycznego w swoim życiu?” mogą być przesłankami decyzji o zawężeniu lub rozszerzeniu spektrum stosowanych instrumentów wsparcia w ramach zarządzania zorientowanego na zdarzenia krytyczne w życiu pracowników.

Implikacje kosztowe stosowania ww. instrumentów są zróżnicowane. Tabela 1 zawiera przykładową typologię tych instrumentów (przynależnych do jednej z trzech ww. kategorii) ze względu na kosztochłonność (specyfika firmy może bowiem determinować ową kosztochłonność). Jej treść wskazuje, które instrumenty powinny stanowić przedmiot szczególnego zainteresowania w ramach controllingu kosztów.

Jeśli wśród faktycznie stosowanych instrumentów przeważać będą te o raczej wysokiej kosztochłonności, a liczba zdarzeń krytycznych wymagających ich zastosowania będzie wyższa od przewidywanej, to niestety ograniczenia budżetowe mogą skłonić do, przynajmniej czasowego, ,zawieszenia” ogólnej dostępności tychże instrumentów i ograniczenia ich bądź to do najpoważniejszych przypadków (zdarzeń krytycznych), bądź do określonej grupy pracowników, na przykład most value employees (pracowników przynoszących organizacji najwyższą wartość) [Stotz 2007, s. 116].

\section{Controlling jakości}

Jakość implementacji koncepcji zarządzania zorientowanego na zdarzenia krytyczne w życiu pracowników można spróbować zdefiniować, posługując się uniwersalnymi definicjami jakości L. Harveya i D. Greena (za: [Dahlgaard, Kristensen, Kanji 2000, s. 23-26]). Tak więc według definicji tradycyjnej (jednego z trzech wariantów definicji opartej na wyjątkach) wdrożenie koncepcji pozwoliłoby na uzyskanie unikatowego kapitału ludzkiego, przy czym ta unikatowość wyrażałaby się w wyjątkowo wysokiej wrażliwości na potrzeby innych. Z kolei zgodnie z definicją doskonałości (drugim wariantem definicji opartej na wyjątkach) jej wdrożenie zbliżyłoby jakość kapitału ludzkiego w zakresie kompetencji społecznych właśnie do stanu doskonałości, a zgodnie z definicją standardową (trzecim wariantem definicji opartej na wyjątkach) - do wysokiego standardu. Osiągnięcie stanu ,najlepszej praktyki” w stosowaniu koncepcji zarządzania zorientowanego na zdarzenia krytyczne w życiu pracowników to sedno definicji perfekcji (jednorodności), zaś zharmonizowanie go ze strategią (ogólną i personalną) - definicji dostosowania do przeznaczenia. Jeśli 
chodzi o definicję wartości stosownie do ceny, to zwraca ona uwagę na opłacalność stosowania koncepcji. W rachunku tej opłacalności uwzględnić trzeba by także efekty społeczne. Ostatnia z definicji jakości ww. autorów - definicja transformacyjna zakładałaby, iż wdrożenie koncepcji zarządzania zorientowanego na zdarzenia krytyczne w życiu pracowników podwyższyłoby wartość dodaną na pracownika, a także - zwiększyłoby znaczenie zarządzania partycypacyjnego w organizacji.

Uzyskanie wysokiej jakości (niezależnie od tego, jak ona jest definiowana) wymaga poniesienia kosztów jakości. Podstawą ich wyróżnienia, także dla potrzeb controllingu personalnego, może być na przykład klasyfikacja wg Johna Banka [1996]. Tabela 2 podaje przykłady kosztów jakości przy implementacji koncepcji zarządzania zorientowanego na zdarzenia krytyczne w życiu pracowników, które mogą być wykorzystane dla tych potrzeb.

Tabela 2. Przykładowe koszty jakości implementacji koncepcji zarządzania zorientowanego na zdarzenia krytyczne w życiu pracowników

\begin{tabular}{|l|l|}
\hline \multicolumn{1}{|c|}{ Grupa kosztów jakości } & \multicolumn{1}{|c|}{ Przykłady } \\
\hline Koszty profilaktyki & $\begin{array}{l}\text { Koszty partycypacji pracowników w określaniu listy } \\
\text { instrumentów wspierania ich w przypadku zdarzeń krytycznych }\end{array}$ \\
\hline Koszty oceny & $\begin{array}{l}\text { Ocena implikacji kosztowych stosowania różnych wariantów } \\
\text { instrumentów wspierania pracowników przez organizację }\end{array}$ \\
\hline Koszty błędów wewnętrznych & $\begin{array}{l}\text { Koszty redefinicji listy instrumentów wsparcia przed ich } \\
\text { zastosowaniem w praktyce }\end{array}$ \\
\hline Koszty błędów zewnętrznych & $\begin{array}{l}\text { Koszty redefinicji listy instrumentów wsparcia po ich } \\
\text { zastosowaniu }\end{array}$ \\
\hline Koszty przekroczenia wymagań & $\begin{array}{l}\text { Stosowanie - w stosunku do jednego pracownika - zbyt wielu } \\
\text { instrumentów wsparcia o zbliżonym kierunku oddziaływania }\end{array}$ \\
\hline $\begin{array}{l}\text { Koszty straconych możliwości } \\
\text { (utraconych korzyści) }\end{array}$ & $\begin{array}{l}\text { Wykorzystywanie w praktyce zbyt wąskiego spektrum } \\
\text { instrumentów wsparcia i/lub wykorzystywanie ich - bez względu } \\
\text { na możliwości finansowe organizacji - tylko w odniesieniu } \\
\text { do most value employees, z pomijaniem most growable employees } \\
\text { i below zero employees* }\end{array}$ \\
\hline
\end{tabular}

*Kategorie pracowników wyróżniane w literaturze przedmiotu [Stotz 2007, s. 116] ze względu na generowane przez nich przychody dla organizacji.

Źródło: własne przykłady do typologii kosztów jakości przedstawionych w [Bank 1996].

W oparciu o koszty jakości wymienione w tabeli 2 mogą być konstruowane m.in. następujące wskaźniki controllingowe:

- koszty profilaktyki w stosunku do kosztów zgodności (koszty profilaktyki i koszty oceny łącznie) lub w stosunku do kosztów jakości ogółem,

- koszty oceny w stosunku do kosztów zgodności lub w stosunku do kosztów jakości ogółem,

- koszty błędów wewnętrznych w stosunku do kosztów niezgodności (koszty błędów wewnętrznych i koszty błędów zewnętrznych łącznie) lub w stosunku do kosztów jakości ogółem, 
- koszty błędów zewnętrznych w stosunku do kosztów niezgodności lub w stosunku do kosztów jakości ogółem,

- koszty przekroczenia wymagań w stosunku do kosztów niezgodności lub w stosunku do kosztów jakości ogółem,

- koszty straconych możliwości w stosunku do kosztów jakości ogółem.

\section{Controlling efektywności}

Controlling efektywności, uwzględniający dwie zmienne (obejmujące różne rodzaje efektów i nakładów), jest trudniejszy w realizacji od controllingu kosztów i jakości, w związku z czym nie dziwi określanie go (np. przez R. Wunderera) najwyższym stopniem controllingu.

W zarządzaniu zorientowanym na zdarzenia krytyczne w życiu pracowników chodzi o zaprogramowane efekty dla pracowników. Oczekuje się jednak, iż mogą one także przynieść firmie korzyści wizerunkowe oraz korzyści w postaci większego zaangażowania ze strony pracowników po tym, jak nie będą już doświadczać w takim stopniu jak na początku skutków zdarzenia krytycznego. Efekty dla pracowników, uzyskane dzięki zastosowaniu ww. instrumentów wsparcia, mają głównie charakter niematerialny (czasowe odciążenie od pracy bądź umożliwienie jej wykonywania na zmienionych zasadach), zazwyczaj krótkotrwały (z wyjątkami dotyczącymi treści pracy i aspektów z nią się wiążących). Pomimo tego mogą dla zainteresowanych mieć podstawowe znaczenie. Zapytanie o to znaczenie może być przedmiotem zapytań w ramach list kontrolnych. Uzyskiwane odpowiedzi powinny być przesłanką do ewentualnej modyfikacji instrumentów wsparcia (ich treści, momentu czasowego bądź sekwencji stosowania). Odpowiedzi te muszą być uzyskiwane w określonym czasie po zastosowaniu tychże instrumentów, tj. ex post. $\mathrm{W}$ ramach controllingu sposób dokonywania tej oceny może być realizowany w sposób bezwzględny (porównanie spodziewanych i faktycznie uzyskanych efektów) lub względny (porównanie ocen efektów zastosowania tych samych instrumentów wsparcia u różnych pracowników). Omawiane efekty można też analizować pod kątem ich powiązania (w znaczeniu definiowanym w literaturze przedmiotu [Chrisidu-Budnik i in. 2005, s. 145]). Dotyczy to przypadku, gdy jednocześnie wobec tego samego pracownika i w odniesieniu do tego samego zdarzenia krytycznego stosowane są (symultanicznie bądź sekwencyjnie) różne instrumenty wsparcia. Tak więc z efektami skrajnie kumulatywnymi można mieć przykładowo do czynienia, gdy zastosuje się urlop bezpłatny, a potem - adaptację po przerwie w pracy. Przykładem efektów ściśle kumulatywnych może być aplikacja urlopu wypoczynkowego „W nietypowym terminie" wraz z przesunięciem terminu oceny okresowej, zaś efektów zmiennie kumulatywnych - zmiana treści pracy i przedłużenie terminu jej wykonania. O odbiór tych efektów w sensie pomocy w sytuacji zdarzenia krytycznego można pytać pracowników w ramach list kontrolnych. 
Wykorzystywanie controllingu efektywności wymaga odpowiedzi na pytanie, czy efekty stosowania koncepcji zarządzania zorientowanego na zdarzenia krytyczne mają charakter mierzalny. Efektem tym - z perspektywy pracodawcy - ma być wyższa wydajność pracy pracownika po uporaniu się przez niego z trudną sytuacją wywołaną ww. zdarzeniem/,łańcuchem” zdarzeń krytycznych. Może być z tym problem, gdyż wydajność ta może być rezultatem różnych przyczyn, a nie tylko pochodną implementacji koncepcji. W związku z tym można mówić o trudnej mierzalności tak rozumianych efektów stosowania instrumentów wsparcia. Nie powinno to oznaczać rezygnacji z ich stosowania, lecz jedynie konieczność zastąpienia mierników/wskaźników listami kontrolnymi. Wydaje się, iż odpowiedzi na pytanie o wydajność pracy po zastosowaniu instrumentu wsparcia powinni udzielać przełożeni pracowników (lub ewentualne dane do oceny mogłyby być zbierane drogą - opisywanej w literaturze przedmiotu - oceny 360 stopni).

Controlling efektywności zakłada odniesienie efektów do nakładów. Jeśliby koncepcję zarządzania zorientowanego na zdarzenia krytyczne w życiu pracowników potraktować jako formę inwestycji w (indywidualny) kapitał ludzki, to rozważyć można by [Lipka 2010, s. 131-133] w odniesieniu do jej wdrażania następujące rodzaje nakładów: przygotowawcze, kreatywne, „koherencyjne”, na doskonalenie procesów, realokacyjne oraz na zarządzanie ryzykiem personalnym. Nakłady przygotowawcze obejmują m.in. nakłady na aktualizację bazy danych dotyczących stanowisk pracy i pracowników. Są one podstawą decyzji o wyborze adekwatnego instrumentu wsparcia. Niekiedy trzeba połączyć („skojarzyć”) różne instrumenty, co wymaga pracy koncepcyjnej (nakładów kreatywnych) i nakładów „koherencyjnych”

Tabela 3. Przykład interpretacji potrzeby „,ingerencji controllingowej” przy wdrażaniu koncepcji zarządzania zorientowanego na zdarzenia krytyczne w życiu pracowników

\begin{tabular}{|l|l|l|}
\hline $\begin{array}{c}\text { Ocena efektów (wydajności pracy } \\
\text { pracowników po zastosowaniu } \\
\text { instrumentu wsparcia) }\end{array}$ & $\begin{array}{c}\text { Ocena faktycznych nakładów } \\
\text { na zastosowanie instrumentów } \\
\text { wsparcia w porównaniu z nakładami } \\
\text { zakładanymi }\end{array}$ & $\begin{array}{c}\text { Potrzeba ,ingerencji } \\
\text { controllingowej” }\end{array}$ \\
\hline Wyższe & Wyższe & $?$ \\
\hline Wyższe & Niższe & Nie \\
\hline Wyższe & Porównywalne & Nie \\
\hline Niższe & Wyższe & Tak \\
\hline Niższe & Niższe & $?$ \\
\hline Niższe & Porównywalne & Tak \\
\hline Porównywalne & Wyższe & Tak \\
\hline Porównywalne & Niższe & Nie \\
\hline Porównywalne & Porównywalne & Nie \\
\hline
\end{tabular}

Objaśnienie: ? - w zależności od przyjętych „obszarów tolerancji”.

Źródło: opracowanie własne. 
(gdy trzeba zadbać o spójność ich jednoczesnego stosowania wobec różnych osób tak, by nie zakłócić na przykład pracy zespołów). Pracownicy powinni współuczestniczyć w wyborze korzystnych dla nich (i możliwych do zastosowania w danym momencie z perspektywy firmy) instrumentów wsparcia. Współpraca w tym zakresie wymaga doskonalenia, co też wiąże się z ponoszeniem nakładów. Stosowanie niektórych instrumentów (np. zmiany formy organizacji pracy) wymaga realokacji i związanych z nią nakładów. Nakłady na zarządzanie ryzykiem personalnym dotyczą przede wszystkim oszacowań prawdopodobieństw i skutków wyboru niewłaściwych dla danego pracownika instrumentów wsparcia.

Przynajmniej w początkowej fazie rozwoju controllingu personalnego (przy jego niższym stopniu zaawansowania [Lipka 2015, s. 161-168]) można ograniczyć się do list kontrolnych, tj. pytań do przełożonych pracowników i/lub działu ds. HR o to, czy poniesione nakłady (łącznie oraz w odniesieniu do ich poszczególnych rodzajów) są: wyższe, niższe bądź porównywalne do zakładanych (gdyż sednem controllingu jest śledzenie odchyleń) oraz czy ich rzeczywiste rozłożenie w czasie nie odbiega od planowanego.

Następnie należałoby zestawiać odpowiedzi dotyczące efektów i nakładów, co powodować powinno ,ingerencję controllingową" lub ją wykluczyć (por. tab. 3).

\section{Zakończenie}

W opracowaniu podano przykłady - odnoszących się do kosztów, jakości i efektywności - mierników/wskaźników oraz pytań z list kontrolnych, możliwych do zastosowania przy controllingu implementacji koncepcji zarządzania zorientowanego na zdarzenia krytyczne w życiu pracowników. Rozwinięto tym samym przyjętą na wstępie tezę. Podane przykłady należy traktować jako egzemplifikację. W ramach kontynuacji analiz w tym zakresie może być bowiem poszerzona ich specyfikacja na przykład o zastosowanie modelu Kano do oceny postrzegania przez pracowników zastosowanych wobec nich instrumentów wsparcia. Związany z nim controlling jakości nie stanowi wprawdzie najwyższego stopnia controllingu, ale świadczy o uwzględnianiu potrzeb różnych interesariuszy.

\section{Literatura}

Armutat S. (Hrsg.), 2009, Lebensereignisorientiertes Personalmanagement. Eine Antwort auf die demografische Herausforderung. Grundlagen, Handlungshilfen, Praxisbeispiele, W. Bertelsmann Verlag, Bielefeld.

Bank J., 1996, Zarzadzanie przez jakość, Gebethner i S-ka, Warszawa.

Böhne A., 2009, Lebensereignisse im Überblick, [w:] Armutat S. (Hrsg.), Lebensereignisorientiertes Personalmanagement. Eine Antwort auf die demografische Herausforderung. Grundlagen, Handlungshilfen, Praxisbeispiele, W. Bertelsmann Verlag, Bielefeld. 
Chrisidu-Budnik A., Korczak J., Pakuła A. i Supernat J., 2005, Nauka organizacji i zarzadzania, Kolonia Limited, Wrocław.

Dahlgaard J.J., Kristensen K., Kanji G.K., 2000, Podstawy zarządzania jakościa, Wydawnictwo Naukowe PWN, Warszawa.

Greenleaf R.,1977, Servant-leadership: A journey into the nature of legitimate power and greatness, Paulist Press, New York.

Heszen I., Sęk H., 2007, Psychologia zdrowia, Państwowe Wydawnictwo Naukowe, Warszawa.

Hochschild A. R., 2009, Zarządzanie emocjami. Komercjalizacja ludzkich uczuć, Wydawnictwo Naukowe PWN, Warszawa.

Lipka A., 2010, Inwestycje w kapitat ludzki organizacji w okresie koniunktury i dekoniunktury, Oficyna a Wolters Kluwer business, Warszawa.

Lipka A., 2015, Stopień zaawansowania controllingu personalnego - kryteria oceny, [w:] Górski P. (red.), Zmiany demograficzne i społeczne w Polsce i Europie wyzwaniem dla nauki i praktyki zarządzania, Wydawnictwo AGH, Kraków.

Lipka A., Waszczak S., Król M., Giszterowicz A., 2018, Empatyczne zarządzanie w czasach performatywnej kreatywności, CeDeWu, Warszawa.

Sekuła Z., 1999, Controlling personalny. Część 2: Strategie personalne, zadania i narzędzia controllingu personalnego, Ośrodek Postępu Organizacyjnego, Toruń.

Stotz W., 2007, Employee Relationship Management. Der Weg zu engagierten und effizienten Mitarbeitern, Oldenbourg Wissenschaftsverlag, München.

Wunderer R., 2000, Enwicklungstendenzen im Personalcontrolling und der Wertschöpfungsmessung, „Personal”, nr 6, s. 303. 